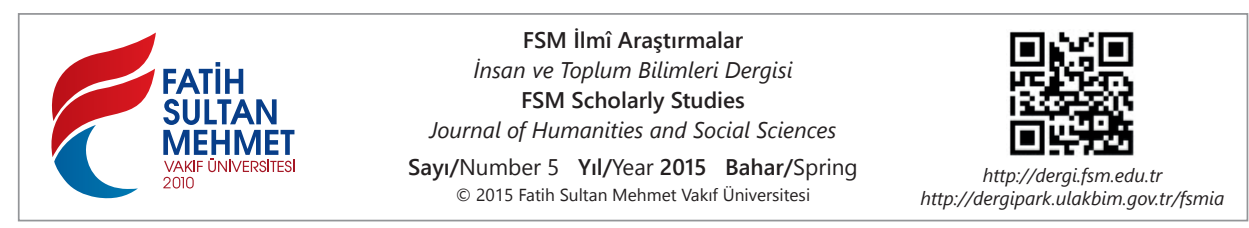

\title{
Mustafa Kutlu'nun Anadolu Yakası Adlı Eseri Üzerine Metinlerarası İlişkiler Bağlamında Bir İnceleme
}

\author{
Mesut Koçak*
}

\section{Özet}

Bu makalede Mustafa Kutlu'nun Anadolu Yakası isimli hikâye kitabı, Metinlerarası İlişkiler yöntemiyle incelenmektedir. Yazı, önce Metinlerarasılığın kökeni, çerçevesi ve ilkeleri üzerinde durmakta, daha sonra Anadolu Yakası metnine söz konusu ilkeler çerçevesinde diğer metinlerin nasıl ve ne şekilde dâhil edildiğini, Kutlu'nun sanat anlayışına göre bu kullanımların neye tekabül ettiği irdelenmektedir. Buna göre, Mustafa Kutlu'nun hikâye metninde alıntı, gönderme, anıştırma ve öykünme gibi teknikler uyguladığı tespit edilmiş, postmodern bir yazar olmamasına rağmen Kutlu'nun metinlerarasılığ 1 kullanma şekli ve anlayışı incelenmiştir.

Anahtar Kelimeler: Mustafa Kutlu, hikâye, Anadolu Yakası, metinlerarasılık.

\section{A Review in the Context of Intertextuality Anadolu Yakası by Mustafa Kutlu}

\section{Abstract}

In this article, Mustafa Kutlu's story book, Anadolu Yakast, is studied according to the intertextual relations method.The article firstly dwells on the origin, framework and principles of intertextuality, secondly, within the framework in question, how and in what way the other texts are included in the text of Anadolu Yakast, and lastly why Kutlu uses these methods. Accordingly, it is stated that Mustafa Kutlu used some techniques such as quotation, allusion, implication and emulation. Furthermore, it is examined that how Kutlu uses intertextuality eventhough he is not a postmodern author.

Keywords: Mustafa Kutlu, story, Anadolu Yakası, intertxtualitiy.

* Arş. Gör., Fatih Sultan Mehmet Vakıf Üniversitesi Edebiyat Fakültesi Türk Dili ve Edebiyatı Bölümü, İstanbul/Türkiye, mkocak@fsm.edu.tr 


\section{Giriş}

Metinlerarasılık kavramı, bir metnin kendinden önceki ya da kendi zamanındaki metinlerden bağımsız olarak (tek başına) bir anlama sahip olamayacağı düşüncesinden doğar. "Her anlatı bir kültürün içinde yer alır, bu nedenle, yalnız yaşadığımız dünyanın dil dışı gerçekliklerine değil, aynı zamanda kendisinden önceki yazılı ve sözlü öteki metinlere de göndermelerde bulunabilir."' Bu göndermeler, Allen'e göre, bilinçli yapılabileceği gibi bilinçaltının metne dökülmesi şeklinde de yapılabilir. Ne şekilde olursa olsun yazılan ya da ağızdan çıkan her söz söyleşim (dialogic)'dir. Metnin ya da sözün mantı̆̆ı daha önceki söylemlere ve bunların nasıl alındığına bağlıdır. ${ }^{2}$ İki ya da daha fazla metin arasındaki bu alışverişi, konuşmayı ve söyleşimi yakalamak ise okura düşer. Dolayısıyla klasik okuma biçiminden tamamen farklı olarak, okurun bir metni okurken başından sonuna kadar aktif olmasını zorunlu kılar. ${ }^{3}$ Bu kuramı ilk kez 1966 yılında ortaya atan isim, Mihail Baktin'in dialogism ${ }^{4}$ kuramından etkilenen Julia Kristeva'dır. Kristeva'ya göre her metin bir anlatılar mozaiğidir. Her metin başka metinlerin kesişim noktası olarak oluşur. Metinlerarasılık, kavram olarak yeni olsa da tekniğin kullanımı eskidir.

Kristeva'ya göre "Yazar, metnini kendi orijinal fikirlerinden yaratmaz. Kendinden önce var olan metinlerden devşirir. Ona göre metin, metinlerin değişimiyle meydana gelir ve bu değişimin meydana geldiği alan da metinlerarasılıktır." 5 Bir metnin edebi değeri de metinlerarasılıktan kaynaklanır. Kristeva’nın kuramı, Roland Barthes'ın çalışmaları ile desteklenmektedir. Barthes, yazarın sadece eskiyi/öncekini taklit ettiğini, hiçbir zaman orijinal bir dil olamayacağını, yazarın tek gücünün yazıları harmanlamak olduğunu söyler. Şu halde yazarın orijinal olarak kendini ifade etmesi de sadece ve sadece hazır edilmiş sözcüklerden ibarettir. Bu sözcüğün kelimeleri bile ancak başka sözcüklerle açıklanabilir. Bu böyle sonsuza kadar giden bir süreçtir. Bu bağlamda rahatlıkla denebilir ki metinlerarasılık teorisi anlamın kaynaği konusundaki geleneksel düşünceleri yok eder. Sabit bir gösterilen olduğu iddiasındaki gösterge merkezli görüş de anlamın ilahi olduğu iddiasındaki yazar merkezli görüş de reddedilir. ${ }^{6}$ Her metni bir metinlerarası olarak tanımlayan Barthes, onda "farklı şekillerde değişik metinler yer aldığını

1 Ayşe (Eziler) Kıran-Zeynel Kıran, Yazınsal Okuma Süreçleri (Dilbilim, Göstergebilim ve Yazınbilim Yöntemleriyle Çözümlemeler), Seçkin Yayıncılık, Ankara 2007, s. 359.

2 Graham Allen, Intertextuality (The New Critical Idiom), Roudledge, London, 2000, s. 19.

3 Graham Allen, a.g.e., s. 7.

4 Dialogism (söyleşimcilik): Bakhtin'in teorisine göre, her söylem tarihsel ve kültürel bağlam içinde kendinden önceki söylemlerle çakışır. Her söylemin içine başka söylemler karışır ve başka söylemlerle karışmayan söylem yoktur. Dialogism ile ilgili olarak daha ayrıntılı bilgi için bkz: Graham Allen, a.g.e., s. 21-29.

5 Graham Allen, a.g.e., s. 35.

6 Graham Allen, a.g.e., s. 13-14. 
ve eski kültüre ait metinlerle hâlihazırdaki kültür tarafindan üretilen metinlerin metni meydana getirdiğini" söyler.

Riffaterre, az da olsa Kristeva'dan ayrılarak kendine özgü bir metinlerarasılık kuramı ortaya koyar. Riffaterre'in farkı, ondan öncekilerin yadsıdığ 1 okuru kuramının içine katması ve metinlerarasıllğ 1 okur-metin ilişkisine göre tanımlamasıdır. "Metinlerarasılı̆̆ın her şeyden önce bir okuma etkinliğine bağlı olduğunu" belirterek okura önemli bir işlev yükleyen Riffaterre, "metinlerarasılı̆̆ın bir metindeki varlığını okurun okuma eylemine ve hafızasına" bağlayarak kuramı alımlama estetiği çerçevesine oturtmuş olur. Ona göre, "metinlerarasilık, okurun kendinden önceki ve sonraki bir eser ile başka eserler arasindaki ilişkileri algllaması"dır. Çünkü, "Metinler okuyucuyu metin dışı bir gerçekliğe değil, başka metinlere gönderirler."

Gerard Genette'e göre de bir metnin edebiliğinin temel ölçütü metinlerarasıl1ktır. Genette, metinlerarasılık olmadan metnin bir saatlik zahmete bile değmeyeceğini ifade eder. ${ }^{9}$ Kendinden önceki metinlerarasılık tanımlarını da dikkate alan Genette, kuramı ilk defa sistemli bir sınıflandırma içinde ele alarak metinlerarasılığa son şeklini verir. ${ }^{10}$ Ona göre "okurun, bir eserin kendinden önceki ve sonraki eserlerle kurduğu ilişkiyi anlaması metinlerarası ilişkiler"dir ve "tüm yazarlar tek bir kitap yaratırlar ve tüm kitaplar geniş bir kitap, sonsuz tek bir kitaptır."11

Metinlerarasılıkta yazar, başka metinlere ve sözlere (romanlar, hikâyeler, masallar, atasözleri, deyimler, özlü sözler, türküler, şarkılar, şiirler, konuşmalar, filmler, reklamlar, senaryolar vb.) kendi metninde yer verir. Bunu yaparken alıntıladığı bu unsurları ya değiştirerek veya dönüştürerek ya da değiştirmeden veya dönüştürmeden kullanır. Yazar, kendi metnine sadece biçimsel olarak başka sözleri, söylemleri ve metinleri alarak değil; onların üslûplarını taklit ederek de başka metinlere gönderme yapabilir. Doğrudan veya dolaylı, biçimsel veya biçemsel olsun bütün bu göndermeler metnin bağımsızlı̆̆ını ortadan kaldırırken onu kültürel ve tarihsel bir sürekliliğin parçası haline getirir.

Bir metnin, başka bir metinle kurduğu ilişki, 'alıntı', 'gönderge', 'gizli alıntı / aşırma', 'anıştırma', 'yansılama / parodi', 'alaycı / gülünç dönüştürüm', 'öykünme / pastiş' yöntemleri ile ortaya konur. Yazar bilinçli ve/ya bilinçsiz olarak bu yöntemlerle / yollarla metnine başka metinleri, sözleri ve söylemleri katar. ${ }^{12}$

7 Roland Barthes, The Rustle of Language, (Translate: Richard Howard), University of California Press, California, 1989, s. 53.

8 Kubilay Aktulum, Metinlerarası İlişkiler, Öteki Yayınevi, Ankara, 2000, s. 60-61.

9 Ayşe (Eziler) Kıran-Zeynel Kıran, a.g.e.,s. 359.

10 Kubilay Aktulum, a.g.e.,s. 81.

11 Ayşe (Eziler) Kıran-Zeynel Kıran, a.g.e.,s. 359.

12 Bu yöntemlerle ilgili detaylı bilgi için bkz: Kubilay Aktulum, a.g.e., s. 94-133. 
Postmodern anlatının en önemli tekniklerinden biri olan metinlerarasılık, sadece postmodernist yazarların başvurduğu bir teknik değildir. Özellikle 1980'lerden sonra Türk edebiyatında postmodernist yazarlar dişında da ${ }^{13}$ bu tekniği kullananlar olmuştur. Bu isimlerden biri de Mustafa Kutlu'dur. ${ }^{14}$

Bu makalede, ilâhi sözün var olabileceğini yok sayan, orijinal söylemi reddeden metinlerarasılığın, hayatı ve sanatı yaratıcının güzelliğinin aksi olarak gören bir yazarın hikâyesinde nasıl ve ne için var olduğu incelenecektir.

\section{Mustafa Kutlu'nun Anadolu Yakası'nda Metinlerarasılık}

Mustafa Kutlu'nun hikâyelerinde, başka metinlere biçim ve biçem olarak göndermelerde bulunma niteliği, Yokuşa Akan Sular'dan itibaren hep var olagelmiştir. ${ }^{15}$ Mustafa Kutlu, bu anlatı niteliğini Anadolu Yakası ${ }^{16}$ adlı hikâyesinde de sürdürür. Anadolu Yakası'nda 'alıntı', 'gönderge', 'gizli alıntı / aşırma', 'anıştırma' ve 'öykünme / pastiş' gibi metinlerarasılık yöntemleriyle deyimlere, atasözlerine, şiirlere, filmlere, eserlere, yazarlara göndermede bulunarak, hikâye metnini başka metinlerle ilişkilendirmiştir.

\section{Alıntı}

Bakhtin, her metni diğer metinlerin alıntılarıyla oluşmuş bir yapı olarak görür ve böylece her metnin bir diğerinin içinde emilip dönüştürüldüğünü söyler. ${ }^{17}$ $\mathrm{Bu}$ bağlamda Metinlerarasılıkta en çok kullanılan tekniklerden biri olan alıntıdır. Alıntı sayesinde yazar, kendi düşüncelerini daha güçlü hale getirir. Yazar, alıntıyı

13 Postmodernist yazarlar olmamalrına rağmen Fatma Aliye, Mehmet Akif, Peyami Safa gibi birçok yazarın eserleri metinlerarasılık bağlamında incelenmiştir. Örnek olarak bkz: Kadriye Alev, "İstiklâl Marşı ”nın Kültürel Kodları ve Metinlerarası İlişkiler”, FSM İlmî Araştırmalar İnsan ve Toplum Bilimleri Dergisi, S. 3, Y11: 2014, s. 11-25., Tülay Gençtürk Demircioğlu, “Hayattan Kurmacaya: Fatma Aliye Hanım'ın Dört Romanında Metinlerarası İlişkiler”, Uluslararası Sosyal Araştırmalar Dergisi, Volume: 3, Issue: 13, Year: 2010, s. 104-109., Cemile Kaygısız, "Bir Tereddüdün Romanı'na Metinlerarasılık Bağlamında Peyami Safa'nın Hayatı ve Eserleri Üzerinden Bakmak", Uluslararası Sosyal ve Ekonomik Bilimler Dergisi, Volume: 1, Issue: 2, Year: 2011, s. 35-38.

14 Necip Tosun da Kutlu'nun postmodern bir yazar olmadığ kanaatindedir. Bkz: http://tosunnecip.blogcu.com/oykude-bir-imkan-olarak-postmodern-acilim-necip-tosun/2788894

15 Kutlu'nun bu anlatı tekniğini kullanması birçok çalışmaya da konu olmuştur örnek olarak bkz: Prof. Dr. M. Fatih Andı, "Metinlerarası İlişkiler Açısından Mustafa Kutlu'nun Bu Böyledir İsimli Eseri”, Hikâyenin Bugünü Bugünün Hikâyesi 80 Sonrası Türk Hikâyesi Sempozyumu, Ümraniye Belediyesi, İstanbul, 2008, s. 71-82. ve Lale Qasimova, "Metinlerarası İlişkiler Açısından Mustafa Kutlu'nun Beşlemesi”, A.Ü.Türkiyat Araştırmaları Enstitüsü Dergisi (TAED), S.46, Y11: 2011, s. 61-86.

16 Mustafa Kutlu, Yokuşa Akan Sular, Dergâh Yayınları, İstanbul 2012.

17 Julia Kristeva, Desire in Language: a semiotic approach to literature and art,Thomas Gora, Alice Jardine and Leon S. Roudiez (trans.), Leon S. Roudiez (ed.), Columbia University Press, New York. 1980, s. 66'dan aktaran Graham Allen, a.g.e., s. 39. 
başka bir yazardan yapabileceği gibi kendi yapıtlarından da yapabilir. Böylece metin 'anlamsal' ve 'izleksel' olarak da desteklenmiş olur. ${ }^{18}$ Alınt1, Anadolu Yakası'nda da en çok dikkat çeken tekniklerden biridir. Metinde, atasözlerinden, deyimlerden, şiirlerden, türkülerden alıntılar yapılmak suretiyle hikâyeye derinlik katılmıştır. Meselâ, hikâyenin ana karakteri Muzo Gönül, eşi ile tanışmasını şöyle anlatır:

“... Vardım kuyu başına. Öyle sessiz duruyorum. Bunun da başı önünde. Kova kuyuda ama heyecandan çekemiyor.

Elimi atıp kovanın ipini aldım. O sırada elim eline değdi.

- Tipkı türküdeki gibi.

- Nasil?

- Eli elime değdi de

Hem ben yandim hem kendi.

..."19

Hatay/Şenköy yöresine ait bu türkü, anlatıyı - "tıpkı türküdeki gibi” ifadesi ile- desteklemekle kalmaz; aynı zamanda onu duygu yönünden de zenginleştirir.

Hikâyenin bir başka yerinde Muzo Gönül, gazeteci Erol'a köyüne olan özleminden bahsederken, bu özlemin aslında insanın vatanına duyduğu özlem olduğunu ifade eder ve sözlerini Akif'in bir mısrası ile somutlaştırırken, anlatıyı izleksel olarak da desteklemiş olur:

“... Bu susuz dereler, bu çorak tepeler, işte şu dökülen ter sayesinde vatan oluyor, özleniyor. Sade bu değil tabii. Akif' in o meşhur mısraı da geliyor hatırına.

- Hangisi

- Şüheda fişkirır toprağl sıksan şüheda ...”20

Muzo Gönül, gazeteci Erol ile Türkiye'nin geçirdiği değişimi konuşurken özellikle Turgut Özal döneminin bu değişmeyi hızlandırdığını, Özal'ın Türkiye'yi değiştirdiğini söyler. Bu değişmenin kimi yönden iyi kimi yönden kötü olduğunu ifade eden hikâye kahramanı, Özal'ın bir sözünü alıntılayarak sözlerini destekler:

“- Bir yanından bakarsan iyi. Serbestlik geldi, millet nefes aldl. Öte yandan bakarsan kötü. Uyanıklara gün doğdu. Başbakan "Benim vatandaşım işini bilir" dedi ya, barajın kapağını açtı. Hayali ihracat, çeteler, devleti soymak hepsinin temelleri atıldl." ${ }^{21}$

18 Kubilay Aktulum, a.g.e., s. 94-101.

19 Mustafa Kutlu, Anadolu Yakası, Dergâh Yayınları, İstanbul 2012, s. 44.

20 Anadolu Yakasl, s. 74.

21 Anadolu Yakast, s. 88. 
Burada alıntılanan cümle her ne kadar bir metne değil; bir kişinin anlık söylemine de ait olsa, o söz (bir de başbakan gibi meşhur birinin sözü ise) diğer sözlerden/söylemlerden ayırt edilir ve muhakkak kültürel bir arka plana yerleşir. O kültürün ürünü olarak çeşitli metinlere malzeme de olur. Nitekim bu söz, gazetelere haber, köşe yazılarına da konu olarak metinleşmiştir. Özal'ın yıllar önce söylediği bu söz -çoğu kişi için bilindik olmasına rağmen- hikâyenin kahramanına tekrar ettirilmiş, kurgunun bir parçası haline getirilmek suretiyle, 'anlamsal' ve 'izleksel' olarak hikaye desteklenmiştir.

Hikâyenin kahramanı Muzo Gönül, köyde kıt kanaat geçinirken ayağına gelen kısmeti anonim bir dörtlükle özetler:

“... Derken derken. Hani berber dükkânlarında, eski manifaturacılarda olurdu. Şöyle bir levha:

Ne lazımdır sana gezmek

Semerkand'ı buhara'yı

Sana taksim olan kismet

Bulur arayl, arayl

..."22

Muzo Gönül, aydın olmanın, kültürlü olmanın sadece okumakla olmayacağını, bunun için kişinin önce kendisini tanıması gerektiğini söylerken Bursalı Tâlib'in bir mısrasını alıntılar: "Kişi kendini bilmek gibi irfan olmaz." ${ }^{23}$ Beytin aslı şöyledir: "Keşf-i insâf kadar kâmile mizan olmaz / Kişi noksanın bilmek gibi irfân olmaz".

Muzo Gönül, aydınların taşraya dair görüşlerini eleştirirken bir hadis alıntısı yaparak kendi düşüncelerini pekiştirme yoluna gider: "Cemaatte rahmet vardır diyor Peygamberimiz." 24

Metinde, taşra ve taşradaki Türk evleri konuşulurken hikâye kahramanı Muzo Gönül, Türk evlerinin içi ile dış1 arasındaki farkı Nedim'in meşhur beytinden alıntı yaparak vurgular: "Ne demiş şair "Meyhane mukassi görünür taşradan amma / bir başka letafet var içinde”. Beyti eksik söyledim belki ama meramımı ifade eder." ${ }^{25}$ Anlatıc1 kahraman, beyti eksik söylemiş olabileceğini belirterek okuyucunun söylemi sorgulamasını ister. Böylece hem düşünce hem de izlek zenginleştirilmiş olur. Beyit gerçekten de eksik söylenmiştir, aslı ise şöyledir: "Mey-hâne mukassî görünür taşradan ammâ / Bir başka ferah başka letâfet var içinde"26

22 Anadolu Yakasi, 110.

23 Anadolu Yakasi, s. 126.

24 Anadolu Yakasi, s. 127.

25 Anadolu Yakasl, s. 131.

26 Nedîm Divânı, (Haz: Prof. Dr. Muhsin Macit), Kültür Bakanlığı Yayınları, Ankara, 2012, s. 326. 
Muzo Gönül, taşra ile merkez arasındaki farktan bahsederken Hasan Alî Yücel'den de bir şiir dizesi alıntılanır: “... O güzelim konaklar sadece Safranbolu'da yok. Üsküp'te, Kemah 'ta, Ermenek'te, Kula'da, Eğin'de de var.

Ama dedim ya bu eski taşra. Yeni taşra böyle değil. O da merkezin taklidi. "Eskiyi unut, yeni yolu tut" dediler; Ístanbul'u da yıktık, taşrayı da..." 27

Metinde Hasan Alî Yücel'in 23 Nisan için yazdığ1 "Eskiyi unut / Yeni yolu tut / Türklüğe umut / Sen ol çocuğum.” dizelerinden yapılan bu alıntı, metinde aktarılan düşünceleri destekler. Ayrıca "dediler" ifadesi ile tırnak içinde verilen sözün metin dışı olduğu iyice kesinlenir. Okuyucu bu ifade ile alıntı yapılan metne ve onun içeriğine yönlenmiş olur.

Hikâye kahramanının televizyonla ilgili düşüncelerinin aktarıldığı bölümlerde de Karagöz ve Hacivat oyununun perde gazellerinden metne alıntı yapılır:

“- Sinema, evet teknik olarak Batılı ama o da bir "hayal perdesi”.

- Yani?

- Yani bir nevi Karagöz. Perde, ışık, gölge. İnsanlar olup bitenleri gerçek değil, şarka mahsus sembol olarak algllyyor. Rüya gibi. Ayrica bilirsin, Karagöz'ün perde gazelleri tasavvufidir. Bak sana aklımda kalan iki beyit okuyayım:

Sûret-i zâhiri bir zull-ı hayaldir perde

Âlem-i kevni temâşaya misaldir perde

Bu perde çeşm-i ehl-i zâhire bir nakş-i sûrettir

Rumuz erbâbına ammâki temsil-i hakikattir

..."28

Yine kahramanın televizyon macerası ile ilgili olarak, merkezde büyük bir televizyon kurma hayalinden söz edilirken, söylenilmek istenilen şey, Yahya Kemal'in Deniz Türküsü şiirinde geçen "İnsan âlemde hayâl ettiği müddetçe yaşar" 29 mısrası üzerinden söylenir: “- Ooo! İnsan dünyada hayal ettiği sürece yaşarmış.

- Söyleyen doğru söylemiş. Hülyası olmayınca hayatın ne tadı var. Yahya Kemal'in miydi bu?

..." 30

Dikkat edilirse alıntı, asıl mısranın biçemi değiştirilerek yapılmıştır. Ancak anlam olarak bir fark yoktur ve devamında da Yahya Kemal'e ait olup olmadığ

27 Anadolu Yakast, s. 132.

28 Anadolu Yakasl, s. 138-139.

29 Yahya Kemal, Kendi Gök Kubbemiz, Yapı Kredi Yayınları, İstanbul, 2005, s. 65.

30 Anadolu Yakasi, s. 145. 
sorgulanarak onun mısrası olduğu sezdirilmiştir. Böylece metnin anlamı hem derinleştirilmiş, hem de "Yahya Kemal'in miydi bu?" sorusu ile okuyucuya bir kapı aralanmıştır.

Muzo Gönül, televizyon kurma hayalini gerçekleştirmek için çareler ararken yıllar önce babasının İstanbul'da çalıştığı yıllarda Mecidiyeköy'ün merkezinde yıllar önce bir arsa satın aldığına dair anlattıklarını hatırlar. Televizyon almak için aradığı kaynağı böylece bulan Muzo Gönül bu durumu, "Aramakla bulunmaz ama bulanlar ancak arayanlardır." sözü ile açıklar. Bu söz Bayezid-i Bistami’ye ait olmakla birlikte isim söylenmemiştir. Ancak metinde tırnak içinde verilmiş olması sebebi ile söylemin metin dışı olduğu sezdirilir. Böylece metin anlamca zenginleştirilirken, okuyucuya da yeni bir pencere açılmış olur.

Hikâyenin diğer kahramanı gazeteci Erol (ki, hikâyenin asıl anlatıcısı odur), Muzo Gönül'ün almaya karar verdiği HïT TV'nin sessiz ve atıl vaziyetini, Bayburtlu Zihni'nin “Vardım ki yurdundan ayak götürmüş / Yavru gitmiş ıssız kalmış otağ / Camlar şikest olmuş, meyler dökülmüş / Sakiler meclisten çekmiş ayă̆gl" dörtlüğünün ikinci mısrası ile özetler:

“... Koca bina sessiz.

- Sanki Bayburtlu Zihni’nin şiiri. Hani bestelenmişti ya.

Muzo "lafimı kestin lan” mânasina yüzünü ekşitiyor.

- Neymiş o?

- Yavru gitmiş, ıssız kalmış otağı.

- Ha! Şu şarkı. Tamam. Öyle...”

Kanal çalışanlarından Dursun Ali’nin, kanalın bir diğer çalışanı Büşra'ya olan karşılıksız sevdası ve bu sevdanın kanalda duyulup kızın da durumdan rahatsız olması sonucu Muzo Gönül, Dursun Ali'yi Ankara'ya göndermek ister. Fakat Dursun Ali, Büşra'yı ancak köyüne dönüp kendini tabiata vererek unutabileceğini söyler ve istifa eder. Bunun üzerine Muzo Gönül, Dursun Ali’nin durumunu Karacaoğlan'ait iki mısra ile şöyle yorumlar:

“... Oğlanın gözleri dolmuş. Muzo kalkıyor:

- Burayı özlemeyecek misin?

Dursun Ali elini öpmek için eğildiğinde o bir damla yaş istifa dilekçesinin üzerine damllyor. Sartlip ayrllyyorlar. Dursun Ali:

- Özlerim elbette, diyor.

Muzo onu da geçiriyor kapıya kadar. 
Kapı kapanınca orada kalıyor. Bana dönerek:

- Sevda sevda derler be hey yârenler / Bilmeyene bir acayip hal olur.

Bu bir uzun havadir biliyor musun?

..." 32

Karacaoğlan'ın "Sevda sevda derler be hey yârenler / Bilmeyene bir acayip hal olur / Varıp bir klz on yediye girince / Açılmadık bir tomurcuk gül olur" dörtlüğünün ilk iki mısrasının alıntılanması ile metin anlam bakımından daha yoğun, biçem bakımından ise daha duygu yüklü bir hale gelir. Dursun Ali'nin belki de sayfalar sürecek ruhsal ve psikolojik durumu bu iki mısra ile kısa ve vurucu bir şekilde anlatılır.

Muzo Gönül, Erol'a müzik hakkındaki düşüncelerini söylerken “Müzik çıkmazda. Çünkü insanımız çıkmazda" ifadesini kullanır. Bunun üzerine Erol, "Turgut Uyar söylemişti bunu, altmışl yılların başında, "Şiir çıkmazda, çünkü insan çıkmazda" diye." ${ }^{33}$ sözleri ile araya girerek Muzo Gönül'ün sözlerini değiştirdiği söylemin sahibini açıklar. Böylece kahramanın müziğe dair söylemi Turgut Uyar'ın söylemi ile kesişir ve anlam tek boyuttan kurtularak bir başka boyut daha kazanır.

Anadolu Yakası hikâye metninde alıntı bu örneklerle sınırlı değildir. Yazar metnin içine onlarca atasözü, deyim ve popüler kültüre ait söylem alıntılayarak anlatımı zenginleştirir; anlamı derinleştirir.

\section{Gönderme}

Gönderme, bir eserden alıntı yapmaksızın, o metnin ya da yazarının adını söylemekle yetinmektir. Böylece alıntı yapmadan, o metne ya da yazara gönderme yapılmış olur. Gönderme, herhangi bir yazarın bir metnine yapılabileceği gibi, popüler olan ya da olmayan kültürel bir unsura da yapılabilir. ${ }^{34}$ Anadolu Yakası'nda metinlerarasılık tekniklerinden sayılabilecek unsurlardan biri de göndermedir. Hikâyede filmlere, yazarlara ve eserlere göndermeler yapılmaktadır.

Hikâye kahramanı Muzo Gönül, ilk gördüğü filmin "Beyaz Yele" olduğunu, taşrada "Spartaküs" ve "Ben Hur" gibi filmlerin çok izlendiğini söyler. ${ }^{35}$ Çocukluğunda okuduğu kitaplardan bahsederken, “...Bir de Kiyamet ve Ahiret diye bir eser. Dili ağırdı pek anlayamadım." ${ }^{36}$ diyerek Gazzâlı̂’nin eserine gönderme yapar. Hikâye kahramanlarından Şeref'in macerası anlatılırken Malkoçoğlu ve Karaoğlan filmlerine gönderme yapılır:

32 Anadolu Yakasi, s. 170.

33 Anadolu Yakası, s. 198.

34 Graham Allen, a.g.e., s. 101-102.

35 Anadolu Yakası, s. 38-39.

36 Anadolu Yakasi, s. 42. 
“... İlk çocuk erkek oldu. Şeref'in yürüyüşü değişti. Kasım, kasım kasıllyor. Oğlanin adını Kahraman koydu.

- Vay be!

- Ya Kahraman. Sen say Malkoçoğlu, yahut Karaoğlan. El kadar çocuğu alıp köy içinde geziniyor. Ulan ayıp, ayıp, dedim dinletemedim ..." ${ }^{37}$

Şeref' in hikâyesi anlatılırken gazeteci Erol, "Yahu hayatı filim olacak adam, bir nevi tutunamayan." sözleri ile metinde Oğuz Atay'ın Tutunamayanlar adlı eserine gönderme yapılır. Böylece metin anlam ve izlek bakımından desteklenmiş olur.

Muzo Gönül, köyde geçirdiği günleri ve köyünün doğasını tasvir ederken Erol, bu tasvirleri yapan Muzo Gönül'ü Tarkovski’ye benzetir:

"Kuru otlar bastıkça çıtırdıyor, her birinden ayrı bir koku yükseliyordu. Dă̆dan gelen serin yel kekik kokuyordu. Yürüdüm, yürüdüm. Eskiden kuzu otardlğımız yerlerden geçtim. Yemlik yedim, kuzu kulağı kopardım. Önümde ufuk. Isşte bu, şehirde görülmeyen bir şeydir. Şehirde binalar, arabalar, kalabalık insanın üzerine gelir. Onu sindirir, bir zavallı kılar. Düzlük öyle değil, kendini özgür hissediyorsun. Sanki kollarını kaldırsan uçacaksın.

- Abi film çekmeye başladın sen. Tarkovski oldun sanki." 38

Muzo Gönül, televizyonu değerlendirirken şöyle der: “... anladim ki bu âlet kapitalizmin kendi hükmünü yürütmesi için icat ettiği âletlerden biri. Bir iletişim âleti gibi gözüküyor. Evet bu doğru ama yüzde on. Yüzde doksan bir eğlence âleti. Bir yazarın ifadesi ile "öldüren eğlence. "39 Burada gönderme yapılan yazar, Neil Postman; eser ise Gösteri Çağında Kamusal Söylem adlı eserdir. Metinde yapılan bu gönderme ile anlatıcının söylemi, gönderme yapılan söylemle birleşmiş böylece verilmek istenen mesaj daha güçlü bir hale gelmiştir.

Kurgunun ilerleyen bölümlerinde Erol ile Muzo Gönül arasındaki konuşmanın konusu sanata ve tiyatroya gelir. Muzo Gönül, tiyatronun yerlileşmediğini ama konu olarak milliliğin ilgi gördügünü belirtir ve örnek olarak da Namık Kemal'in Vatan yahut Silistre' adlı oyununu gösterir. Bunu yaparken Namık Kemal' in ismini söylemez:

“... Alafranga kesim hariç tiyatroya yüz vermedi halkımız.

- Bir türlü yerlileşemedi, belki ondandir.

- Yerlileşemedi, çünkü yerlilik daima küçümsenmiştir.

37 Anadolu Yakasl, s. 55.

38 Anadolu Yakasi, s. 75.

39 Anadolu Yakasl, s. 121. 
- Ama millî olmak ilgi gördü, değil mi?

- Doğru konulursa. Vatan yahut Silistre'den beri böyle..."40

Muzo Gönül, hayalini kurduğu televizyon kanalını kurmak için gerekli sermayeyi sağlayacak olan babasının yıllar önce Mecidiyeköy'den satın aldığ 1 arsanın tapusunu bulunca, "Yeşilçam ăgzı ile diyelim: "Bekle beni İstanbul"." 41 diyerek, Yeşilçam filmlerinde sık kullanılan bir söyleme de gönderme yapmış olur.

Arsayı satacağı Sarı Süleyman adlı iş adamı üzerinden zengin iş adamlarının, siyasetçilerin ve Allah vergisi kabiliyeti olanların gülüşlerinin gerçek olup olmadığını anlamanın imkânsız olduğu söylemi geliştirilirken, Muzo Gönül, "Entelektüeller diye bir kitap okumuştum. Jan Jak Ruso'dan, Hemingvey'e kadar pek çok düşünür ve sanatçının gerçek yüzünü anlatıyordu. Şoke oldum. Bulursan $o k u$." ${ }^{22}$ diyerek Paul Johnson'1n kitabına göndermede bulunur. Böylece anlatıcı kahraman kendi söylemini örnekler ve güçlendirir.

Hikâyenin sonunda Erol, Muzo Gönül'e "Gönlünden, ulan elime bir firsat geçse de şunun filmini çeksem dediğin bir hikâye geçmedi mi?" diye sorunca Muzo Gönül, "Geçti. ... Medine Müdafaası ..." cevabını verir ve hikâye bu sözle sona erer. Bu son sözde de anlatıcı kahraman İslam ve Osmanlı tarihi için çok önemli bir tarihi hadiseye, Fahreddin Paşa'nın kahramanlığı ile özdeşleşmiş Medine Müdafaasına gönderme yaparak, kurguyu biçimce bitirse de izleksel olarak okuyucunun zihninde devam ettirir.

\section{Anıştırma}

Anıştırma, metinlerarasılıkta çok kullanılan yöntemlerden biridir. Anıştırma telkin ve ima ile bir başka metni hatırlatmaktır. ${ }^{43}$ "Gönderme"de olduğu gibi sadece edebi metinlere ve sanat metinlerine değil; gündelik veya tarihi kişi, olay, durum ve eserlere "anıştırma" da yapılabilir. Edebiyat lügatimizde bu tekniğin karşıllı̆ı "telmih"tir. ${ }^{44}$ Anadolu Yakası hikâye metninde de birçok defa anıştırma yapılır.

Patronu, Gazeteci Erol'a Anadolu Yakası adlı kanalı bilmediği için "Bileceksin ciğerim, bileceksin ki, bu âlemde bir adın olsun." ${ }^{45}$ diyerek ögüt verir. Aynı doğrultuda Muzo Gönül, Gazeteci Erol'un söyleşi teklifini "Yapalım elbette. Bizim de bu âlemde kendimize göre bir adımız var"46 sözleri ile kabul eder. Bu iki konuşmada da "âlem" ve "adımız" söylemleri Bâkî'nin "Minnet Hudâya devlet-i

40 Anadolu Yakası, s. 138.

41 Anadolu Yakası, s. 149.

42 Anadolu Yakast, s. 164.

43 Kubilay Aktulum, a.g.e.,s. 109.

44 M. A. Yekta Saraç, Klâsik Edebiyat Bilgisi Belâgat, İstanbul, 3F Yayınları, 2007, s. 82.

45 Anadolu Yakası, s. 6.

46 Anadolu Yakası, s. 9. 
dünyâ fenâ bulur / Bâkî kalur sahîfe-i 'âlemde adumuz" ${ }^{47}$ beyitini üstü kapalı olarak çağrıştırır.

Muzo Gönül, insanın ve tabiatın ölüm karşısındaki çaresizliğini "Yaprak da fani insan da" ${ }^{48}$ sözleri ile ifade ederken "Her canlı (nefis) ölümü tadacaktır. (Ankebut, 57)" âyetine telmihte bulunmaktadır. ${ }^{49}$

Televizyon hakkındaki satırlarda söylenen, "Bu alet nefse hitap ediyor, kalbe değil. Nefis de dokuz canlıdır bilirsin. İnsanın dünyadaki en büyük imtihanı nefisle mücadele." ${ }^{50}$ sözleri ile tasavvuftaki nefsin yedi merhalesi olduğu görüşünü ima etmektedir.

Muzo Gönül, kurduğu kanala slogan olarak “demokratik kanal'1 seçer. Demokrasi ile ilgili düşüncelerini söylerken "Bu rejimde "bilenlerle bilmeyenler" eşittir." söyleminde bulunur. Bu söylemde de bir telmih vardır. Yazar, okuyucuyu Zümer sûresinin 9. âyetine götürür: "De ki: Hiç bilenlerle bilmeyenler bir olur mu?"

Televizyon hakkında konuşan Muzo Gönül'e Erol, otomobil, televizyon ve bilgisayarın yirminci yüzyılı etkileyen üç alet olduğuna dair sözlerini hatırlatınca Muzo Gönül, "Ben dedimse doğrudur. Ben sizin babanızım." diye cevap vererek 1990'lı yılların popüler bir şarkısını anıştırmış olur. Barbaros isimli bir şarkıcı tarafından seslendirilen bu şarkı bir popüler kültür ürünü olarak metne dâhil edilir.

Hikâye metininde anlatıcı kahraman aracılığı ile yapılan bu anıştırma veya telmihler, anlatımı tekdüzelikten, okuyucuyu da sıradanlıktan çıkararak aktif metin / aktif okuyucu boyutuna çıkarır. Söylemler zenginleşir ve anlatı her anıştırmada bir ivme kazanır.

\section{Öykünme (Pastiş)}

Öykünme (pastiş), bir metnin üslûbu ile ilgilidir. ${ }^{52}$ Yani herhangi bir metnin, dönemin ya da kişinin üslûbu ve tarzı taklit edilir. Öykünen ile öykünülen arasındaki taklit ilişkisi, metnin başından sonuna kadar devam edebilir ya da metnin

47 Bâkî Dîvânı, (Haz: Prof. Dr. Sabahattin Küęük), Kültür Bakanlığı Yayınları, Ankara, 2012, s. 194.

48 Anadolu Yakasi, s. 75.

49 Ayetlerin metinlerarasılık bağlamında kullanılıp kullanılamayacağını sorgulayan Prof. Dr. Hasan Akay: "Metinlerarasılığın "Artık ilk metin yok, kopya bir metin var," anlayışı, bu tahrifatı (kutsal metnin tahrifatını), ilk metnin kazınarak yerine beşerî metinler yazılarak oluşturulan üretimi- meşrulaştırmak için türetilmiş bir bahane olabilir mi? ... Bilinçli yapıldığı takdirde sonucu kültürel tahrifata, gaflet ve hatta dalâlete kadar gidebilir.” demektedir. Bkz: Hasan Akay, "Metinlerarasılık ile İlham Perileri Arasında Gidip Gelen Düşünceler", Karabatak, Sayı: 20, May1s-Haziran 2015, s. 18-29.

50 Anadolu Yakasl, s. 123.

51 Anadolu Yakasi, s. 181.

52 Kubilay Aktulum, a.g.e.,s. 133. 
kimi bölüm ya da parçalarında yer alabilir. Anadolu Yakası hikâyesinde kurgu, baştan sona nehir söyleşi üslûbu çerçevesine oturtulmuştur. Bu bağlamda hikâyenin bir kurgu, kurgunun ise hayali olduğundan hareketle, bu metnin baştan sona kadar bir "pastiş" örneği olduğunu söylemek yanlış olmaz. Bununla birlikte hikâye metninde parça parça olarak değişik öykünme (pastiş) örnekleri de vardır. Burada örneklenecek olanlar da bu söylemlerdir.

Anadolu Yakası'nda kurgu, nehir söyleşi çerçevesine oturtulduğundan metin diyaloglar şeklinde ilerlese de hikâyenin asıl anlatıcısı Erol'dur. Anlatıc1, Muzo Gönül ile söyleşi yapmaya nasıl karar verdiğini ve kitabı neden yazdığını anlatırken şunları söyler: "Ey okur! Bu şöhreti dünyayı tutmamış, tanınmamış etmemiş, kendi halindeki adamın hayatı işte karşınızda. İster okuyun, isterseniz "Ya, ne var bunda, ortalama bir adam işte, gözüme yazık" deyip bırakın. Karar sizin." 53

Anlatıc1, "Ey okur!" ve "Karar sizin." sözleri ile okuru da kurguya dâhil eder. Yazarın okuyucusu ile geliştirdiği bu sohbet havası Ahmet Midhat Efendi'de görülen geleneksel meddah anlatımına özgü bir üslûptur. Kutlu'nun, Kapıları Açmak, Huzursuz Bacak, Tahir Sami Bey'in Özel Hayatı gibi eserlerinde de görülen bu üslûp, modern kurgu ile geleneksel anlatıyı birleştirir. Çağın da Kutlu ile Ahmet Midhat arasındaki bu üslûp benzerliğine dikkat çeker: "Mustafa Kutlu son dönem eserlerinde Ahmet Midhat Efendi'ye benzer şekilde geleneksel meddah anlatımına özgü bir anlatıcı tavrı geliştirmistir. Bu tavır, önceki eserlerinde de görülmekle birlikte, son dönem eserlerinde daha belirgin bir hal almıştır." 54

Televizyon kanalı almak için kaynak arayan Muzo Gönül'ün babasından küçükken "masal gibi" dinlediği arsayı hatırlaması, köyüne arsanın tapusunu bulmak için gidişi ve sonrası, metnin genel kurgusu dışına çıkılarak Muzo Gönül tarafından değil, anlatıcı tarafından ve masal üslûbu ile anlatılır:

"Muzo o heyecan ile köye gitmiş. Camiden çıkan babasını bulmuş, tenhada tapuyu sormuş. Babası elini sakalına atıp bir zaman düşünmüş. Sonra hatırlamış. "Ya! Evet, öyle bir evrak vard, ama ben onu anana verdiydim, sakla bunu dediydim" diye cevaplamıs.

Muzo anasına koşmuş, anası da hatırlayamamış. Muzo "Gözünün yağını yiyim ana, çalıştır şu saksıyı, hatırla. Çok mühim çok”. Kadın o yana bakmış, bu yana bakmış yok. Öyle ki evde bakılmayan yer kalmamış. Zaten bir köy evi, ne dolap var ne çekmece, bakılacak yer az. Sonunda kala kala kadının çeyiz sandı̆̆ı kalmış. Kadın "Oğul ben bu sandığl seneler var ki açmadım. Zaten içinde bir şey

53 Anadolu Yakasl, s. 9-10.

54 Sebahattin Çağın, "Mustafa Kutlu'nun Hikâyelerinde Anlatıcı", Aynanın Sırrı: Mustafa Kutlu Sempozyumu Bildirileri, (Haz. M. Fatih And1, Bahtiyar Aslan), İstanbul, İstanbul 2012, s. 180. 
yok" demişse de gözü dönmüş Muzo sandiğı açtırmış..." ${ }^{55}$

Metinde kahramanın kendi ağzından anlatılan bu tapu hikâyesi anlatıcı tarafından kesilerek masalsı bir biçeme dönüştürülür. Yazarın, Muzo Gönül'e söylettiği "Babam inşaatlarda çalışmış. ... Arkadaşlarıyla bir otel odasında veya bir bodrum katında kalırlarmış. Bize masal gibi anlatırdl." ${ }^{56}$ sözleri, masal üslûbuna bir öykünme yapılacağını önceden okuyucuya haber verir. Bu öykünme ile yazar, metni tekdüzelikten kurtarır ve okuyucunun yabancı olmadığ 1 bir anlatı tarzına geçiş yapar.

Anadolu Yakası'nda karşılaşılan bir başka öykünme örneği de, kısacık da olsa Dede Korkut hikâyelerinin üslûbuna yapılan öykünmedir. Muzo Gönül, Sarı Süleyman ile tanışmasını anlatırken zenginlik ve para hakkında da bir şeyler söyler. Bu söylemlerin birinde, "Ulan para, anayı kızdan ayıran para. Ulan menfaat ne diyeyim ben sana insanın kanına girmişsin söküp atmak kolay mı?"57 der. Bu söylem çok açık bir şekilde Dede Korkut Hikâyeleri'nin üslûbunun taklididir. $\mathrm{Bu}$ örnek, Mustafa Kutlu'nun gelenekle olan bağını biçemsel olarak da devam ettirdiğini gösterir.

Anadolu Yakası'ndaki metinlerarasılık örnekleri bunlarla sınırlı değildir. Metin özellikle 'klişe-basmakalıp söz'ler bakımından da hayli zengindir. Ancak bu kullanımlar ayrı bir çalışmayı gerektirecek kadar fazla olduğundan bu çalışmanın dışında bırakılmıştır. 


\section{Sonuç}

Postmodern bir yazar olmamasına rağmen Mustafa Kutlu'nun birçok hikâyesinde olduğu gibi Anadolu Yakası hikâyesinde de metinlerarası unsurlara rastlanır. Metnin kendi kendini var ettiği, yazarın edilgen bir durumda kaldığı, "edebi metnin farkl metinlerin bir kesişim yeri olduğu ya da farklı söylemlerin kolajından meydana geldiği" ${ }^{58}$ savından doğan ve her şey daha önce söylenmiştir görüşünü benimsetmeyi amaçlayan metinlerarasılığın, sanatı "ilâhi sırrın terennümü" olarak gören bir yazar tarafından kullanılması dikkat çekicidir. Gerek yalnız-Âdem'in söyleşimci yöntemden kurtulabileceği sav1, gerekse her metnin bir alıntılar mozaiği olduğu ve başka metinlerin eritilmesi ve dönüşümünden oluştuğu iddiası, Kutlu'nun "ilâhi ahenge iştirak" ve "ilâhi ahengin terennümü" olarak özetlenebilecek sanat anlayışıyla çelişir. Üstelik kuramı ilk kez ortaya atan Bakhtin ve Kristeva'nın bütün metinlerle birlikte kutsal kitapları da içine alan söylemleri, İslâm inancının en temel dinamiği olan Kur'an'ın da bir metin olarak görülmesi anlamına gelir. Bu bağlamda vahiy reddedilmiş olur. Hâlbuki bizzat Kur'an'da vahyin ilahi bir hitap olarak peygambere aktarıldığı, Allah'ın peygamberle konuştuğu vurgulanır. ${ }^{59}$ Şu halde metni başka metinlerin "kesişim alanı" olarak gören ve sadece "yalnız-Âdem'in söyleşimcilikten kurtulabileceğini”" iddia eden metinlerarasıllı kuramı ${ }^{60}$, bu haliyle Mustafa Kutlu gibi sanatını İslâm tasavvufu üzerine bina etmiş bir yazarın hikâyelerinde neden vardır? "Bilinçli yapıldı̆̆ takdirde sonucu kültürel tahrifata, gaflet ve hattâ dalâlete kadar gidebil (ecek) ${ }^{61}$, bu tekniğe Kutlu, nasıl ve hangi niyetle yer vermektedir?

Hasan Akay, "bu noktada yapılması gereken işlem, bu yaklaşımın da zehrini almak suretiyle kullanmaktır." 62 demektedir. Bu incelemenin bir sonucu olarak Mustafa Kutlu'nun yaptığının da bu olduğunu söylemek yanlış olmaz. Kutlu, metinlerarasılığın alıntı, gönderme, anıştırma gibi tekniklerini geleneğin içinde zaten var olan belagata ait birtakım tekniklerle de harmanlar. Nitekim sanat görüşünü anlattığı bir köşe yazısında bu bağlamda söyledikleriyle, sanat anlayışı hakkında ipuçları verir:

58 Kubilay Aktulum, a.g.e.,s. 9.

59 Kiyamet Suresi'nin, “Onu (Kur'an'ı, kavrayıp belletmek için) aceleye kapılıp dilini onunla hareket ettirip-durma. Şüphesiz, onu (kalbinde) toplamak ve onu (sana) okutmak bize ait (bir iş) tir. Şu halde, biz onu okuduğumuz zaman, sen de okunuşunu izle." mealindeki 16., 17., ve 18. ayetleri dolayısıyla anlaşılmaktadır ki, Kur'an, bizatihi beyanına göre bir metin değil, bir "ilâhî söz”, "ilâhî hitap”tır. Nasıl indiği de "Kur'an'ın nüzulü” bahislerinde izah edilmiştir (Örneğin, bkz. Prof. Dr. Muhsin Demirci, "Kur'an Vahyinin Nüzûl Keyfiyeti ve Korunması”, Diyanet İlmî Dergi, Cilt: 46, S. 1, Y11: Ocak-Şubat-Mart 2010, s. 7-32).

60 Prof. Dr. Hasan Akay, "Yoksa bu yöntem, gerçek "şiir"in ve "vahiy”in, çok yönlü bir manevrayla reddedilmesi uğrunda bir "gürültü çıkartma" eyleminden, uygulamalı bir algı operasyonundan mı ibarettir?” diye sorarak bu konuyu tartışır. Bkz: Hasan Akay, a.g.m., s. 18-29.

61 Hasan Akay, a.g.m., s.20.

62 Hasan Akay, a.g.m., s.20 
“... Sanat hakkındaki görüşümü pek çok yerde ifade ettim. Yeri geldi bir kez daha söyleyeyim.

Hani İbrahim Hakk hazretleri:

Mevlâ görelim neyler

Neylerse güzel eyler

Diyor ya. Isşte bu güzellik tüm kainata yayılmıştır. Güzelin ne olduğuna ve estetiğe geçmeden yolumuza devam edelim. Bu güzelliğin temelinde bir "ritim" var ve o bir âhenk uyandırtyor. Seste, renkte, biçimde, harekette hatta duygu ve düşüncede hep vardır. Zerre'den kürre'ye kadar sonsuzluğa uzanan, insan idrakinin kavrayamayacă̆ı ama kalbi açık olanın mutlaka duyacağı bir âhenk ki en çok insana bahşedilmiştir.

Insana düşen şeksiz-şüphesiz-isteksiz-iradesiz-akılsı-fikirsiz bu âhenge iştirak etmektir. Kul olmak budur. Bu âhengin sırr ile dereler çağlar, çiçekler açar, bulutlar uçar, kuşlar öter, mevsimler değişir, çocuklar doğar, iki gönül birbirine akar, aşk doğar. Aşkın ateşi ile şair şiirine, ressam resmine, bestekâr bestesine başlar. Hakk'in güzel kıldiğı âleme bir güzellik katmak için. Şuna emin olunuz.

Kalbe düşen bu güçlü sirda (Hikmet) ızdırap, hasret, dua, vuslat, aciz, teslimiyet; insana verilen her şey vardır. Ve insan bunu terennüm eder.

Ve böylece var olur.

Var ettiği eser esasen ona değil bu sirra aittir. O bir aracıdır. Tipkı Cenab-ı Hakk'ın iradesinin vücut bulması için kendisine tevdi edilen emanete göre hareket etmesi; kendi isteğini Allah'in emrine vermesidir. Cüz'i irade budur. Yok hükmündedir. Ama vardır. Sûfiler bu sebeple "hiç" lafzını çok kullanır..."63

Bu köşe yazısındaki sanat görüşleri, Anadolu Yakası'nda söylediği “.... Kendini bilmek, tanımak; tarihini, geçmişini bilmekle olur. ... Biz Osmanlıca bile bilmiyoruz, dedemizin mezar taşını okuyamıyoruz. Kendi öz kaynaklarımızdan bîhaberiz. ... Seksen sene geçti milleti okumaya alıştıramadık." ${ }^{64}$ sözleriyle birleştirildiğinde Kutlu'nun hikâyelerinde neden başka metinlerle ilişki kurulduğu da açıklanmış olur. Mevla'nın eylediği ve bütün kâinata yayılan güzelliği duyan sanatçı, bu güzelliğin ortaya çıkardığı ritimle âhenge ${ }^{65}$ iştirak ederek, Hakk'ın güzel kıldığ1

63 Mustafa Kutlu, “Ah bu gönül şarkıları”, http://yenisafak.com.tr/yazarlar/MustafaKutlu/ ah-bu-gonul-sarkilari/32108.

64 Anadolu Yakasl, s. 126.

65 Burada, Kutlu'nun hikâyelerini " ritim" ve "âhenk” bağlamında irdeleyen bir yüksek lisans çalışması için bkz. Hüseyin Yılmaz, "Modern Türk hikâyesine Mustafa Kutlu’nun getirdikleri, Fatih Sultan Mehmet Vakıf Üniversitesi, Sosyal Bilimler Enstitüsü, Yüksek Lisans Tezi, İstanbul, 2013, 246s. Ayrıca, Kadriye Alev ve Merve Okuyucu'nun hazırladıkları "Mustafa Kutlu ile Hikâyeciliği ve Hikâyeleri Üzerine Bir Röportaj” için bkz: Kadriye Alev, Mustafa Kutlu'nun Hikâyelerinde Dünya Algısı", Fatih Sultan Mehmet Vaklf Üniversitesi, Sosyal Bilimler Enstitüsü, Yüksek Lisans Tezi, İstanbul, 2013 içinde. 
âleme bir güzellik katmak için insana verilen her şeyi terennüm ederek varlığının farkına varır. Sanatçının eseri aslında Allah'a aittir, yazar sadece bir aracıdır. Yazar cüz'i iradesi ile külli irade karşısında yok hükmündedir.

Bu bağlamda Kutlu, güzel olan her şeyi, "derelerin çağıltısını, çiçeklerin açışını, bulutların uçuşunu, kuşların ötüşünü, mevsimlerin değişmesini, çocukların doğuşunu, iki gönlün birbirine akışını, kalbe düşen güçlü sırla terennüm eden her şeyi yaradanın bir lütfu" olarak dile getirir. "Kendini bilmek, tanımak; tarihini, geçmişini bilmekle olur" sözündeki "kendini bilme"nin ancak Allah'ı bilmekle olacağının farkında olan Kutlu, gelenekle bağını koparmadan, Allah'ın külli iradesi ile, insanların cüz'i iradeleri vasıtasıyla yarattığı her güzel sözü / söylemi eserlerinde kullanır. Kutlu'nun yaptığı sözü çoğaltma, dağıtma, Kristeva'nın tabiri ile mozaikleştirme değil; birleme, teklemedir; 'söz(lerin) ebrûsu'dur. Bu bağlamda Kutlu, metinlerarasılık anlayışı ile postmodern değildir. Metinlerarasılık onun sırtını geleneğe dayama alanıdır. Metinlerarasılık onda sanat anlayışına uygun olarak hayattan devşirilen göz / nazar olarak belirir. Kendi nefsini, dolayısı ile Rabbini bilen bir sanatçı olarak okuyucunun ufkunu da bu yöntemle fakat geleneğe bağlı bir şekilde açar. 


\section{Kaynakça}

Akay, Hasan, "Metinlerarasıllk ile İlham Perileri Arasında Gidip Gelen Düşünceler”, Karabatak, sayı 20, Mayıs-Haziran 2015.

Aktulum, Kubilay, Metinlerarası İlişkiler, Ankara, Öteki Yayınevi, 2000.

Alev, Kadriye, "İstiklâl Marșı"nın Kültürel Kodları ve Metinlerarası İlișkiler”, FSM İlmî Araştırmalar İnsan ve Toplum Bilimleri Dergisi, sayı 3, 2014.

Alev, Kadriye, "Mustafa Kutlu'nun Hikâyelerinde Dünya Algısı", (Yayımlanmamış Yüksek Lisans Tezi), Fatih Sultan Mehmet Vakıf Üniversitesi Sosyal Bilimler Enstitüsü, İstanbul, 2013.

Allen, Graham, Intertextuality (The New Critical Idiom), London, Routledge, 2000 .

And, Fatih, "Metinlerarası İlişkiler Açısından Mustafa Kutlu'nun Bu Böyledir İsimli Eseri", Hikâyenin Bugünü Bugünün Hikâyesi 80 Sonrası Türk Hikâyesi Sempozyumu, Ümraniye Belediyesi, İstanbul, 2008.

Barthes, Roland, The Rustle of Language, trans. Richard Howard, California, University of California Press, 1989.

Beyatlı, Yahya Kemal, Kendi Gök Kubbemiz, İstanbul, Yapı Kredi Yayınları, 2005.

Çağın, Sebahattin, "Mustafa Kutlu'nun Hikâyelerinde Anlatıcı”, Aynanın Strrı: Mustafa Kutlu Sempozyumu Bildirileri, haz. M. Fatih And1, Bahtiyar Aslan, İstanbul, 2012.

Demirci, Muhsin, "Kur'an Vahyinin Nüzûl Keyfiyeti ve Korunması”, Diyanet İlmî Dergi, cilt 46, sayı 1, Ocak-Mart 2010.

Demircioğlu, Tülay Gençtürk, "Hayattan Kurmacaya: Fatma Aliye Hanım’ın Dört Romanında Metinlerarası İlişkiler”, Uluslararası Sosyal Araştırmalar Dergisi, cilt 3, say1 13, 2010.

Kaygısız, Cemile, “Bir Tereddüdün Romanı'na Metinlerarasılık Bağlamında Peyami Safa'nın Hayatı ve Eserleri Üzerinden Bakmak”, Uluslararası Sosyal ve Ekonomik Bilimler Dergisi, cilt 1, say1 2, 2011.

Kıran, Ayşe (Eziler)-Kıran, Zeynel, Yazınsal Okuma Süreçleri (Dilbilim, Göstergebilim ve Yazınbilim Yöntemleriyle Çözümlemeler), Ankara, Seçkin Yayınc1l1k, 2007.

Kristeva, Julia, Desire in Language: a semiotic approach to literature and art, trans. Thomas Gora, Alice Jardine, Leon S. Roudiez, ed. Leon S. Roudiez, New York, Columbia University Press, 1980.

Kutlu, Mustafa, Yokuşa Akan Sular, İstanbul, Dergâh Yayınları, 2012. 
Kutlu, Mustafa, Anadolu Yakası, İstanbul, Dergah Yayınları, 2012.

Qasimova, Lale, "Metinlerarası İlişkiler Açısından Mustafa Kutlu'nun Beşlemesi”, A.Ü. Türkiyat Araştırmalar Enstitüsü Dergisi (TAED), sayı 46, 2011.

Saraç, M. A. Yekta, Klâsik Edebiyat Bilgisi Belâgat, İstanbul, 3F Yayınları, 2007.

Tosun, Necip, http://tosunnecip.blogcu.com/oykude-bir-imkan-olarak-postmodern-acilim-necip-tosun/2788894

Y1lmaz, Hüseyin, “Modern Türk hikâyesine Mustafa Kutlu'nun getirdikleri, (Yayımlanmamış Yüksek Lisans Tezi), Fatih Sultan Mehmet Vakıf Üniversitesi Sosyal Bilimler Enstitüsü, İstanbul, 2013. 
